\title{
"The most eastern of the West, the most western of the East": Energy-transport infrastructures and regional politics of the periphery in Turkey
}

\author{
Bilge Firat ${ }^{1,2}$ \\ 1 Department of Humanities and Social Sciences, Istanbul Technical University, Istanbul 34469, Turkey \\ 2 Department of Sociology, Binghamton University, Binghamton, NY 13902, USA \\ Corresponding author: Bilge Firat; e-mail: bfirat@itu.edu.tr
}

The construction of railroads, highways, pipelines, tunnels, and bridges is a result of an imagined construction of regions and in return helps solidify such imaginations. Critics of the role of technological advancement in fostering social, economic, political, and cultural integration between centers and peripheries argue that many such projects remain as political dreamscapes instead of serving as successful examples of transregional integration. Nevertheless, new political dreamscapes give way to new client networks from the European peripheries, solidified by real material networks of energy and transport. Currently promoting itself as a bridge and energy hub between Europe and Asia, Turkey champions such infrastructural developmentalism. This article examines how some political dreamscapes of energy-transport infrastructures, which are imagined to connect Eurasia to Europe via Turkey, relate to their actual construction. At a time when hopes for Turkey's political integration with its surrounding regions have waned, I critically interrogate whether economic integration by means of material infrastructures for energy and transport can substitute for political forms of integration.

Keywords Energy; Infrastructure; Regionalism; Transport; Turkey

The construction of railroads, highways, pipelines, tunnels, and bridges may arise from a specific imagination of integrated or networked regions. They may also create or intensify real regional networks and integration - albeit often in nonlinear, contradictory ways. Currently promoting itself as a bridge and energy hub between Europe, Asia, and the Levant, the Turkish government champions infrastructural integration to further its position as strong trade partner and political ally of states in these regions. Turkey's economic and politicocultural policies toward former Soviet "Turkic" Republics, its imperial history in the Middle East and North Africa, and, more recently, its pending membership in the European Union (EU) are seen by political and economic elites from the greater region as opportunities. Nevertheless, as in imperial, colonial, and modernizing times alike, tensions and conflicts are inherent in infrastructural regionalism as a project, not the least because infrastructure development is seen both as an all-inclusive solution and as an all-pervading problem (Edwards et al. 2009:365). This article looks into infrastructural regionalism, or region building by means of infrastructural development projects, in Turkey, where large-scale infrastructures currently mediate the exchange of energy commodities (human labor and fossil fuels) between sources from its East and markets to its West.

The study of infrastructure is important from an anthropological perspective because infrastructure materializes energy flows in ways that make power struggles and economic inequalities apparent. Here I explore several energy-transport infrastructure projects, including one subsea tunnel and several pipelines, which I take as materialized power, to chart region-building efforts by Turkish political and economic elites with cross-border implications on economy, society, and politics. 
Energy infrastructures as materialized power embody different interests and power struggles among actors and agents of regional integration wherever they transpire. The recent Turkish surge in infrastructural developmentalism, embodied in many energy-transport projects, comes at a time when Turkey's integrationist aspirations toward the post-Soviet Turkic states that have vast fossil fuel deposits have waned, while its political integration with the EU has also gone into a death spiral. Noticeably, although the European core is experimenting with technology and infrastructure that could foster a "postcarbon society" (decarbonization in EU speak; see European Commission 2010a; Elliott and Urry 2010), the EU ardently supports infrastructural developmentalism to facilitate fossil fuel transport in its peripheries, including Turkey, by politically backing and/or financing projects that would stitch these geographies to one another, helping to build a buffer zone of regional enclaves.

Here I argue that states in European peripheries like Turkey welcome this initiative because they struggle to make their people and territories remain relevant to the EU core by means of networked energy-transport infrastructures that are oriented toward the sustenance of existing and projected European fossil fuel needs, while procuring their own energy sources - a prerequisite for a growing economy, according to energy determinists. To those ends, Turkish elites together with their counterparts from around the world dig through the earth, carve out steel routes, and institute laws and regulations for market formation and corporatization with the long-range hope to turn Turkey into a regional power hub for the accumulation, exchange, and distribution of unspent energy resources. Such infrastructures in return help these elites materialize postdevelopmentalist "political dreamscapes" (Löfgren 2008:195) of their own, but in different and far more contentious ways.

\section{Regionalism by means of energy-transport infrastructures: An anthropological treatise}

Region came to English in the fourteenth century from the Latin words regionem, meaning "direction, boundary, district," and regere, meaning "to direct or to rule" (Williams 1985:264). Since then, a region has been understood as the territory controlled by a regent and his regiment (Bitušíková 2009:30) or a substate administrative unit. Other popular uses of region refer to its cross-border, continental, or substate (cultural) topographies that envelop multiple nation-states, as in the Latin American region, the Franco-Spanish Basque region, the Caucasus, and, more recently, the EU-purported Middle East and North Africa region.

Anthropological engagements with regions have in the main focused on identity matters and cultural politics. But political economy once sat at the heart of cultural analyses of regions in anthropology. Between the 1950s and 1980s, anthropologists came to view regional analysis as a necessary means to research the ways in which people's livelihoods were interlinked, how local-regional economies were socioeconomically and politically articulated to the world economy, and the role of the elites in these processes (Wolf 1956; Schneider et al. 1972; also see Bitušíková 2009; Cole 1977; Wilson 2012). Following Schneider et al. (1972), Cole (1977:365) defined a region as "a unit of political ecology, where local resources and people are organized by an elite which is interposed between community and nation - and which may even bypass the nation in its relations with the world system." As these political elites may "represent a specific economic interest" (Schneider et al. 1972:331), economic interests are typically at the heart of region-building processes.

Scholars also found that a region is a relational construct, a product of historical alliances in economy and politics sustained by ecological arrangements (Roth 2007:20; Williams 1985:264), often overlapping with others due to manifold, competing interests that are involved in their making, which carries not size but space and scale as important analytics (Marchand et al. 1999). Whether calibrated by scale, economy, politics, or identity, a region's relationship to other political ecologies is always unequal and uneven (Smith 2006) - especially where resources are expended without being regenerated. These power inequalities are produced by particular socioeconomic dynamics through time, and as such, energy and infrastructures are fundamental to their making (Roth 2007:21).

In this critical rethinking of regions, an anthropology of European integration also emerged (Boissevain 1975; Cole 1977) as the critique was applied at the European Community level (see Löfgren 1996; Wedel et al. 2005; 
Wilson 1993, 1998), where infrastructure as materialized power for cross-border governance has been central. Throughout the twentieth century, the program to foster infrastructural interdependence between European states, territories, and peoples, or "infrastructural Europeanism" (Schipper and Schot 2011), was promoted as a catalyst for greater economic, political, and social integration in the joint context of nation-state building and cross-national articulation to the world system (Badenoch and Fickers 2010; Högselius 2013; Levinson 2006; Löfgren 2008; Marshall 2013; Peck 1995; Schot 2007; van der Vleuten 2010). Today, constituting "the central nervous system of [Europe's] economy" (European Commission 2010b:5), successful examples of infrastructural Europeanism range from the construction of bridges and tunnels - such as the Øresund Bridge between Denmark and Sweden (Berg et al. 2000; Linde-Laursen 2010; Löfgren 2000, 2004, 2007), the Channel Tunnel (“Chunnel”) between England and France (Darian-Smith 1999), and the Gotthard trans-Alpine railway from Switzerland to Italy (Schueler 2008) - to the building of integrated transport, telecommunications, energy, and market infrastructures among EU member states and between them and European peripheries (Barry 2013; Torsello 2013).

Existing anthropological accounts of large-scale infrastructures in the EU attest to the pivotal role such infrastructures play in European politics, economy, and society. But my contention is anthropological engagement with energy, infrastructures, and the ways in which they are spatially articulated is becoming organized as research topics on their own, that is, not as accidental themes that were encountered when looking for development, colonialism, or modernization (cf. Gluckman 1940). There are now bourgeoning anthropological scholarships on energy and infrastructure that refocus research analytics onto different social groups' engagements with resources and their material - political provisioning, or lack thereof (Anand 2011,2012; Behrends et al. 2011; Dalakoglou 2012; Harvey 2005; Larkin 2008; Latour 1996; McNeish and Logan 2012; Nielsen and Pedersen Schouten 2013; Strauss et al. 2013; von Schnitzler 2008), but there is no consideration of energy and infrastructure. Yet, I would question whether it is analytically desirable, or even possible, to dematerialize energy commodities by stripping them from their materiality. And what are the spatial aspects of the deterritorializing pressure of globalization, a name newly given to justify the old practice of plundering local ecosystems, wherein energy infrastructures often play a key role?

Regions continue to spatialize under so-called deterritorialized globalization. In her critique of globalization, Tsing (2000) suggested scale making as an object of critical anthropological inquiry. Her research model, which I follow in this article, casts a critical lens onto the "ideologies of scale, that is, cultural claims about locality, regionality, and globality; about stasis and circulation; and about networks and strategies of proliferation" by means of refracting "rhetorics of scale as well as contests over what will count as relevant scales" and "projects of scale-making," which refer to "the relatively coherent bundles of ideas and practices as realized in particular times and places" (Tsing 2000:347). Tsing (2000:338) also cautions anyone who wishes to engage in such critical analysis "to avoid letting those who imagine themselves as winners [for example, of infrastructural regionalism by means of energy-transport infrastructure development] call all the terms."

This raises a second conceptual problem regarding shifting scale. Looking at the consumption angle, Chelcea and Pulay (2015) have recently suggested "anthropologizing" infrastructures as materialities that are made sense of at the local level. In his review of the anthropological scholarship of infrastructures, conversely, Larkin (2013) proposed to make sense of them as networked systems, by means of systems analysis. Larkin (2013:328) argues,

Our disciplinary bent is to examine the influence of a road in this part of Peru or that part of Niger rather than to analyze road building as a network. A systems analysis in this regard demands an ethnographic retooling, one in which ethnography might need to be conducted in government centers far from where the actual roads are constructed and might take into account politicians, technocrats, economists, engineers, and road builders, as well as road users themselves.

Networked or not, infrastructures remain "local at all points" because the people who attend to their functioning are local (Latour 1993:117). More significantly, even though the "flows" of people, goods, services, and 
information they carry may be mobile, infrastructures are very much immobile (Larkin 2008:251). As immovable assets, decommissioning has high economic and environmental costs. Once built, infrastructures are here to stay. This fact is magnified by scale. Large-scale infrastructures built from tons of high-cost steel and concrete, such as oil and natural gas pipelines, bridges, roads, and railways, be they "underutilized white elephants," are hardly going to be replaced after they are erected.

$\mathrm{Im} /$ mobility, it has been argued, does not alter the fact that infrastructures become mundane objects of everyday use, turning invisible in time, except when they abruptly stop working because of sabotage, or technical problems, which forces visibility onto them (Bowker and Starr 1999; Edwards 2003; Lakoff and Collier 2010; Lampland and Starr 2009; Nye 2010; Rupp, this issue). Studies of infrastructures in places as diverse as Soviet Russia and colonial-national Nigeria have argued that in such places, infrastructures are far from invisible (Collier 2011; Larkin 2008, 2013). There, however "obtrusive" (Collier 2011), their visibility attests to the symbolic representation of state power, which Mann calls “infrastructural power," or the state's capacity "to penetrate and centrally co-ordinate the activities of civil society through its own infrastructure” (Mann 1984:189) mainly by means of energy provisioning, taxation, military control, and information storage about its citizens. Infrastructural power in Mann's (1984:190) thinking correlates positively with a state's despotic power or its direct power over society, especially in the Global South, including postsocialist peripheries of southeastern Europe, where urban electricity grids, water pipes, and sewage systems sustain the in/visibility debate articulating with inequalities at the world scale, due to past and persistent effects of colonialism and because of modernization and development paradigms (Anand 2011, 2012; Dalakoglou 2012; Harvey 2005; Larkin 2008; Schouten 2013).

In the case of Turkey, large-scale energy and transport infrastructures and those who build, operate, and use them for various commercial reasons mediate between the local and the global and between the national and the supranational. These infrastructures are often ceremoniously erected, boasting of visibility, especially at the beginning of their "social life" (Appadurai 1986), but quickly turn into mundane objects of everyday use. Nonetheless, their mundanity, much like in Continental Europe (see Darian-Smith 1999; Berg et al. 2000), does not automatically remove the public contention that continues to surround them. Their efficacy remains contentious.

The kinds of energy and transport infrastructures I engage here can stand alone. A subsea tunnel does not need a gas pipeline to function, nor does an oil pipeline need a bridge. Although usually some road or rail network is required to physically build pipelines, bridges, and canals, if not for accessibility, then to transfer materials, equipment, and labor to the field sites to make it happen. Individually, these projects are Modernization 2.0, or outcomes of a postdevelopmentist development era, where peripheral states reembrace development as a project to bring about economic growth, technical and scientific progress, labor productivity, exploitation of environment, and massive industrialization on their own terms. Collectively, however, they embody a new region-building paradigm, epitomized in the country's becoming an "east-west energy corridor" (Winrow 2004), a material conduit between markets and resources. They prescribe the cultivation of the land, its people, and their resources at unprecedented speed, suggesting that, in this postdevelopmentist regionalism, infrastructural development is the key-albeit driven by economically, politically, and socially unsustainable interests channeled through muddied waters.

Anthropologists continue to debate appropriate scaling for studies of infrastructure, but here I argue, following Tsing (2000), that the relationship between material energy-transport infrastructures and the political ethos of regionalism heeds us to shift our objective (and methodology) of scholarly inquiry from a strict cultural localism, or universal globalism for that matter, into following difference and the systems that foster and facilitate the production of it through dis/connections, in order to chart ideological-discursive forms of scale making that are manifest in material, tangible forms (also see Humphrey 2003, 2005; Mitchell 2002). Around the Bosphorus, such projects have most recently taken the form of infrastructural development ventures in energy transport, whereby the Turkish political and economic elites engage in deliberate region building driven by hitherto uncharted interests. 


\section{Crossing the Bosphorus - from underneath}

On October 29, 2013, the Turkish Republic's ninetieth anniversary, a subsea tunnel under the Bosphorus for the crossing of high-speed trains was inaugurated by the Turkish president, his prime minister, members of his government, and VIP guests from around the world. Known as Marmaray (a combination of "Marma" from the Marmara Sea and ray, Turkish for "rail") and dubbed as "the project of the century," the 0.87 -mile-long submerged-tube tunnel, the deepest of its kind in the world, is part of a transcontinental rail network of high-speed trains under construction in various parts of Turkey and the neighboring countries of Eurasia. As part of the Trans-European Network for Transport (TEN-T) and the EU-proposed Transport Corridor Europe-Caucasus-Asia, the subsea tunnel will connect to the Baku-Tbilisi-Kars railway under construction in the Turkish northeast (Ziyadov 2005), opening an East-West trade and transit corridor to the former Soviet republics in the Caucasus, "free from Moscow's domination" for the first time since 1883 (Daly 2013; Collier and Kemoklidze 2014). When completed, claimed its proponents, Marmaray would symbolically as well as physically connect Beijing from the Far East with London from the West via Istanbul. It now carries labor commuters during the day and consumer goods at night.

"The dream of our ancestors" in the (then) Turkish prime minister's terms, Marmaray helps found a "new Silk Railroad" of the twenty-first century (Yackley 2013). Speaking at the Third Summit of the Cooperation Council of Turkic Speaking States in Azerbaijan, a truly Turkish initiative within this enduring foreign policy climate, the then Turkish president pointed at "collaborative energy, transport and logistics projects" such as Marmaray that will altogether "aid the development of the entire region" and "transform the Turkic world into the center of the world economy and development" (AzerNews 2013). Post-1989, Turkish elites tried to foster political and economic pan-Turkism based on common religion, ethnicity, and race between Turkey and post-Soviet countries in the Caucasus and Central Asia that are deemed "Turkic," which became especially handy during the construction of the Baku-Tbilisi-Ceyhan (BTC) oil pipeline (Uzer 2011; see later) and is expected to be in other infrastructure development projects.

The Japanese are not a Turkic people, but their interest and investments in infrastructural projects such as Marmaray pay well. After the festivities at the Asian end of the tunnel, the Turkish and Japanese prime ministers moved to the Dolmabahce Palace, the imperial seat of the late Ottoman rulers where the Turkish prime minister keeps his study. Earlier in 2013, major protests against urban redevelopment projects took place in front of this palace for the first time in more than three decades. There, the two prime ministers affirmed their joint commitment to erection of a second nuclear power plant in a Turkish Black Sea town by signing an agreement for strategic cooperation in nuclear science and energy - post-Fukushima.

This Bosphorus crossing, on the table since 1985 (or the 1880s, according to government claims that it is a revived project originally commissioned by an Ottoman Sultan to whom the Turkish prime minister felt affinity; Yackley 2013), cost US\$4 billion, funded primarily by Japanese, Turkish, and European public money channeled through the European Investment Bank (EIB), the Japan Bank for International Cooperation, and Turkish private banks with long-term paybacks and state loan guarantees (Radikal 2014). Even this is a small amount compared to the total cost of large energy and transport infrastructure projects the Turkish government has bid out to consortia of domestic and foreign construction companies: US $\$ 180-250$ billion, roughly equal to the federal bailout cost of Lehman Brothers during the 2008 financial crisis, or one-fourth of Turkey's 2013 gross domestic product (GDP).

Also under construction in the Marmara region, including Istanbul, are two bridges to connect to the new North Marmara Highway hub; ${ }^{1}$ one new airport and one artificial seaway or canal, to be located near a newly developed town east of Istanbul; another underwater tunnel (Eurasia Tunnel); three nuclear power plants (including a Russian and a Franco-Japanese venture); two container terminals; several long-range pipeline networks for natural gas and oil; and numerous small-scale hydroelectric dams on practically any suitable water flow the Turkish government can find. In total, US $\$ 100$ billion will go to energy investments, including power plants, pipelines, compressor stations for both liquidified natural gas (LNG) and non-LNG, and oil and gas storage facilities, whereas US\$150 billion is 
needed for other transport projects, such as the canal, bridges, airports and seaports, railroads, and motorways mentioned earlier. More than one-third of all EIB and European Bank for Reconstruction and Development funds go to energy and transport infrastructures under construction in Turkey. As in the case of the EU (Johnson and Turner 2007:42), such energy infrastructures are valued not so much to generate economic growth on their own but to provide logistics for growth. Such large-scale infrastructural projects and the networks into which they fit will soon turn Turkey into a land with tight connections to and interconnections with the East and the West, a land whose "power in the globalizing world makes itself felt with its ease of access" (Ministry of Transport, Maritime Affairs, and Communications 2011:7) and whose political elites deem it to be "the most eastern of the West, and the most western of the East” (former Turkish EU minister, 61st Meeting of EU - Turkey Joint Parliamentary Committee, March 31, 2009).

If Marmaray was built to transport human energy (in the form of bodies and consumer goods embodying their labor power) from one continent to the other, the pipeline currently being built between Azerbaijan and Turkey-one nation, two states, according to successive Turkish governments since the breakup of the Soviet Union - is meant to transport natural gas. Known as the Trans-Anatolian Pipeline (TANAP), this 1,242-mile-long, 1.2-million-ton steel route with an expected construction cost of US $\$ 10$ billion (well above initial estimates) is to carry 16 billion cubic meters of Azeri gas to European markets all the way through Turkey, if and when it becomes operational as early as 2018 as part of the Southern Gas Corridor. Russia alone satisfies two-thirds of the EU's natural gas demands, which has been the case since the mid-1950s, bringing its own geopolitical complexities into the region (Högselius 2013). Azeri and Turkish planners expect TANAP to connect with the Trans-Caspian Gas Pipeline in the East, a currently negotiated, submarine pipeline between Turkmenistan and Azerbaijan; with the Trans-Adriatic Pipeline in the West, a planned, mixed (land and offshore) pipeline crossing Greece, Bulgaria, Albania, and Italy; and potentially with the "Turkish Stream" from the north, a 565-mile-long Russian Gazprom initiative under the Black Sea that is meant to replace the South Stream to Bulgaria, with a gas capacity four times higher than TANAP. Three-fifth of that gas will supply the Turkish market; the rest will go to Europe.

Although aiming at political, economic, and energy integration between Turkey and Azerbaijan, TANAP will literally slash Turkey from east to west, completing an axis with the BTC pipeline ${ }^{2}$ that crosses the country from north to south, bypassing the Kurdish territories in Turkey, and Armenia (with which both Turkey and Azerbaijan have been in conflict). More than half of the urban population in 21 cities whose territory TANAP will cross voted for the ruling party during the 2013 local elections.

The Nabucco pipeline, TANAP's predecessor and an original native design in which the Turkish engineer-planners took great public pride (Petroleum Pipeline Corporation from Turkey [BOTAŞ] official, personal communication, May 31, 2013), was soon shelved as a "paper pipeline" (Mason and Stoilkova 2012:84) after its political and economic costs were deemed to be too high. In its decade-long social life, Nabucco competed with South Stream to carry Caspian gas to Europe's hub in Austria. Today, neither is on the table. Instead, TANAP and the Southern Gas Corridor replaced them. In the world of infrastructures, competing interests vie for power, and projects' social lives oscillate between "potential" and "prospective."

After Nabucco, Turkish and Azeri politicians and corporate interests debated whether an upgraded version of the existing Turkey-owned BOTAŞ pipe system could still be used to move gas to European markets. The Azeri government and corporate representatives preferred to bypass the Turkish network and chose a new pipeline to be built largely with Azeri capital, with BOTAŞ and British Petroleum owning minority shares (see Figure 1). At the end of the day, Turkish political and technical elites were not happy with their projected minority shares in Nabucco, making Turkey solely a "transit country" rather than an "energy hub" (see later). Turning Azerbaijan into Turkey's biggest energy investor, TANAP is now being built over the most part of Nabucco's planned route.

One interlocutor from the European Commission told me off the record (September 14, 2013) that to build a TANAP-like dependent energy conduit would have been "unthinkable in an EU member state" due to potential strong public opposition such a project may elicit. EU member states in the northern and western parts of Europe 


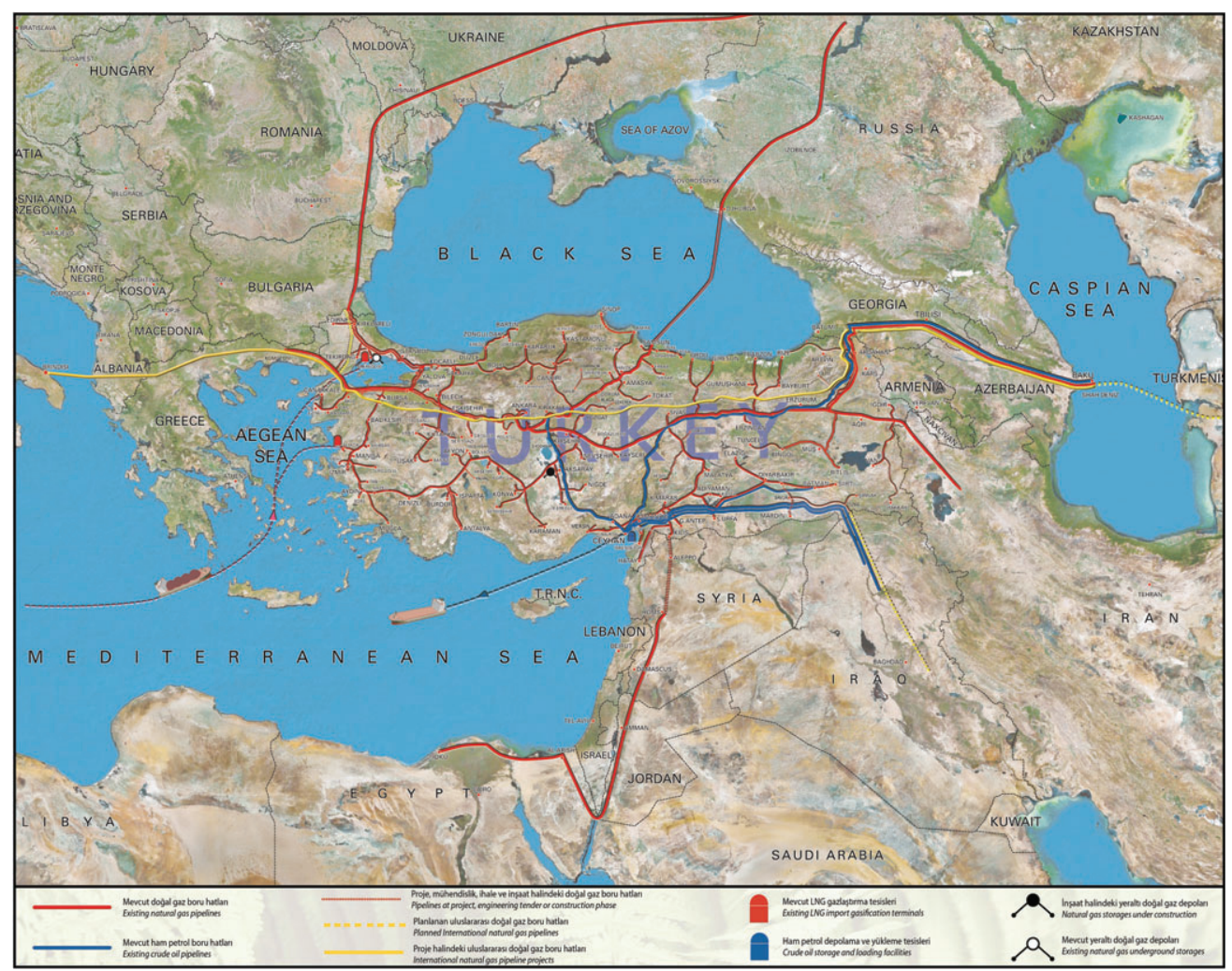

Figure 1 Existing and planned oil and gas pipelines and other energy-transport infrastructures in and around Turkey. Courtesy of BOTAŞ.

have fully or almost fully completed their infrastructural integration with regard to electricity and gas grids and their land (motorways and railroads), air, and sea networks. In these regions, the need is to upgrade existing infrastructures and, to a limited extent, to build infrastructures for a postcarbon society (U.S. Department of Energy official, personal communication, March 14, 2014; see Dracklé and Krauss 2011; de Rijke 2013) and not to invest in fossil futures - unless in others' futures (see roadmap2050.eu). But we were not talking about an EU member state, only an aspirant, Turkey, that aims to meet its own growing energy needs while providing for those of others around it, as it was, according to its elites, stuck "conveniently" between the markets and the resources.

\section{Constructocracy, market building, and interruptions in the periphery}

If it achieves its projected economic growth rate (far above the crisis-stricken EU average and second highest in the world after China), Turkey will face an exponentially growing energy trade deficit. Energy imports in 2013 accounted for 75 percent of Turkey's current account deficit (Business Monitor International 2014). Planned energy-transport infrastructures aim to carry enough gas for a doubling of consumption in this decade (International Strategic Research Organization 2011:1). But two-thirds of supply is guaranteed through existing international purchasing agreements from the mid-1990s, forcing Turkey to pay the same price as EU member states for gas produced mainly in Russia (58 percent of total imports) and Iran (18 percent; Energy Market Regulatory Agency 2013). Despite low per capita energy consumption (one-third of the EU average), certain industrial and transport sectors' roaring need for energy soaks up half of total imports and three-fourths of total natural gas and oil consumption (International Energy Agency 2013). Half of imported oil goes to land transportation, whereas half of the imported natural gas is 
used in electricity generation for consumption in industry and housing. The hope of Turkish authorities is that the newly laid pipelines will provide a way out of the current high-priced oil and gas regime.

There is something about the nature of natural gas as an energy commodity: It demands material conduits (de Rijke 2013; Rogers 2012; Watts 2001); it is best transmitted via pipelines. Otherwise, it must be liquefied (LNG), reducing its volume considerably by cooling it and shipping it in tankers and/or trucks, and then regassed once it reaches its destination, which requires sophisticated and more traditional infrastructures such as LNG terminals and motor-, sea-, and railways. Until an economical system to do otherwise is developed, pipelines are still most economical (Turkish gas contractor, personal communication, September 3, 2013). Although preparations are under way for building several more LNG terminals and gas storage areas, pipelines carried around 83 percent of gas transmitted to Turkey in 2013 (Energy Market Regulatory Agency 2013). The nature of the material-commodity can be altered by technology, but the economic and political cost of doing so is high enough that resources continue to go into new pipeline capacities. But at what risk?

Pipeline transmission's modularity (the ability to shift supply through different routes) is seen as sine qua non for diversifying risk associated with dependency on only a few sources of energy supply. In light of a de facto stalemate in membership talks between Turkey and the EU, Turkish politicians and government officials believe that strategically positioning their pipelines will force the EU to negotiate with them on a more favorable basis. “They need us!" one Turkish official exclaimed to me (September 16, 2013), taking pride in TANAP as a successful example of Turkish-Azeri cooperation and as an alternative to Russia-dominated energy transmission networks via the Ukraine or Bulgaria.

The same official attributed this "success" to the common affinities in language, ethnicity, and religion of the Turkish and Azeri peoples, a remnant of tried-and-failed pan-Turkist foreign policy. Self-orientalizing, he described the culture of energy negotiations he engages in as follows:

When you are brothers [like Turks and Azeris], you communicate and understand each other better. It is also easier to negotiate with Russians than with Europeans. As we go towards the East, communication becomes easier because of the lack of written culture. We do not drown ourselves in details ... . In Brussels, if you want something outside of their given mandate they [EU negotiators] begin stuttering, but not the Russians.

My interlocutor from the construction sector was less confident about the Turkish influence on his Azeri "kinsmen." In energy negotiations, he claimed, one must give something to get something. "As Turkey, what can we give?” he mused. "There are no Azeris shopping at Beyazit ${ }^{3}$ anymore. They shop in London. While I drive a Honda Civic, my Azeri friends drive Mercedes. We can only give our know-how” (September 3, 2013).

Through all this talk of brotherhood, friendly foes, and the indecision of foreign counterparts, Turkish negotiators have one common objective in energy talks: to turn their country into an energy hub, a "geographically fixed [point] on a network infrastructure that allows for the collection, co-ordination and distribution of tangible and intangible products around the network" (Johnson and Turner 2007:17). Once different pipelines run through its territory, Turkey will become an energy hub, enabling it to trade, price, and control energy products that cross its territory freely and without outside interference - or so Turkish authorities hope. This is a far cry from being a "transit country," a mere land conduit, as some EU officials have frequently referred to Turkey (European Commission 2010a, 2010b), terribly irking the country's statesmen. Becoming an energy hub will give Turkey "relevance," another Turkish official explained (Schleifer 2005), for countries around it will become heavily invested in and have a direct "interest" in Turkey's security, which will "matter" to them. To become an energy hub, one needs political stability. When asked about the then-recent crisis in the Ukraine-Russia's neighbor to the west and the primary conduit for its gas destined for Europe, with numerous gas transmitting and storage facilities - and whether the construction of TANAP-like pipelines might increase Turkey's fragile security in the region, my Turkish official interlocutor suggested, "For political stability, you need as many pipelines as possible." 
A Brussels-based Turkish-Cypriot consultant was not all that excited about the construction of energy infrastructure and its potential contribution to regional integration and stability, including overcoming long-standing political and territorial disputes such as in Cyprus: "You cannot connect people with pipelines ... . Energy discourses based on economic arguments will not suffice because pipelines would go through here today, and through there tomorrow" (February 3, 2009). In the eastern Mediterranean, proposals for building an offshore natural gas pipeline from Israel to Turkey via Cyprus and articulating to TANAP are more common now than ever (International Crisis Group 2012), attesting to the belief of many political elites from Turkey that they can pacify existing conflicts and potential risks through infrastructure.

Infrastructural developmentalism in Turkey breeds its own form of government backed by infrastructural power, what one calls a "constructocracy" (Schleifer 2013). In a constructocracy, the domestic economy is driven by the needs and interests of an ever-growing, unevenly developed construction sector and by a government that finds more and more legitimacy and self-esteem in envisioning, building, and ultimately fetishizing infrastructural development projects that are ever bigger and more expensive, but often with no clear policy outlook.

In the case of energy conduits administered by a constructocracy, legal innovativeness, as it pertains to the right to land, is common. Pipelines since the BTC, a "1,099-mile long swath of militarized corporate sovereignty," according to one observer (Reyes 2007:842), enjoy exclusive zones run by their own legal regimes. Until 2039, Turkey, Georgia, and Azerbaijan as "host countries" are barred from "passing new legislation that could affect the profitability of the pipeline." Domestic regulations relating to environmental protection and human rights are undermined; transfers of land and property rights are set unequally; and they directly control the cleanup of spills (Sovacool 2011:617). This "freedom of petroleum transit" was first established as a principle during the negotiations for the construction of the BTC. Inclusive of it, TANAP agreements also attribute the "freedom of transit" to gas "as though it were a rights and duties bearing subject under international law" (Reyes 2007:867).

Granting "freedom of transit" to energy commodities costs Turks their sovereignty. The Turkish government tries different ways to compensate for this cost. More large-scale energy and transport projects are one means to that end, while market building is another. Turkish lawmakers recently passed legislation that institutes an independent regulatory authority for energy markets tasked with regulating natural gas, electricity, petroleum, and LNG product exchanges. In the meantime, most formerly state-owned energy and transport infrastructures were privatized and transnationalized (see Celasun and Arslan 2001; McGowan 1999). The capitalist logic here is quite banal: After privatization, the state continues to receive high revenues in the form of taxes and royalties. Even though this may not be quite the same as jointly owning these establishments, it still ties the state to the companies' well-being (Turkish official, personal communication, September 16, 2013).

The state's interest in the well-being of infrastructure development projects may also come from another source. With a forecasted 5.3 percent real growth in 2014, the construction sector currently accounts directly for more than 6 percent of Turkish GDP and employs 1.5 million people, equaling about 30 percent of nonagricultural production and 10 percent of nonagricultural employment (Business Monitor International 2014; European International Contractors 2012). Construction of energy infrastructures is expected to surpass residential and nonresidential buildings by 2022 (Business Monitor International 2014). However, energy-transport infrastructures contribute little to employment because energy is not a labor-intensive industry. The BTC consortium employed 15,000 short-term workers at the beginning of construction, but since the pipeline's operations began, only 1,000 employees have been retained for ongoing maintenance. A constructocracy, in other words, is not a developmental state, much less a welfare state. Instead, a delicate balance between national sovereignty and energy security, on one hand, and developmentalism linked to economic growth, on the other hand, needs to be carefully set. But relying mainly on borrowed finance (domestic or foreign), imported pipes and other critical materials, and cheap domestic labor, the construction of certain large-scale energy and transport infrastructures, such as pipelines, does not look sustainable from the perspective of sound energy policy or from an economic perspective. 
Even though the Turkish administrators responsible for the timely completion of the Marmaray project pledged to jump off the Bosphorus Bridge in the case of failure to meet the inauguration deadline, also encouraging their Japanese colleagues to sign a document to that end with their own blood, Marmaray broke down a day after it was opened. The official explanation for this failure was a power outage. News of people walking the subsea tunnel by foot in the dark went viral in the social and mainstream media. Some critics blamed it on the failings of the governing party. Expert testimonies from outside the project perimeters indicated that the project may have been rushed owing to the prime minister's megavisions. Public images of water leakages through the tunnel's walls raised such grave suspicions among certain social groups that they refuse to use Marmaray to this day. In return, the Turkish prime minister made statements about how many more miles of roads and highways his government had built compared to the nation's founders at the beginning of the last century. When Marmaray failed to work for several long hours the day after its opening, he blamed it on saboteurs who repeatedly pulled the emergency lever and criticized those who prayed to Allah that the high-speed train would fail.

\section{Conclusion: Connecting people with pipelines?}

Social scientists have long been suspicious of the role of technological advancement in fostering social, economic, political, and cultural integration between the centers and peripheries of nation-states in Europe and in other world regions. Many such projects, critics argue, remain as "political dreamscapes" instead of successful examples of transregional integration (Löfgren 2008:195). But despite criticisms querying the viability of infrastructural regionalism as a working means for transnational regional integration, new political dreamscapes are designed and proposed to new client networks including states from the periphery. Members of the prevailing political and economic classes dream of satisfying energy needs by devising infrastructural projects with uncharted implications and excessive, conspicuous costs that are often borne by others.

Material infrastructures are important "political stories" that anthropologists need to attend to because they embody "particular intentions [and/or their absence/neglect] ... in physical form" (Winner 1980:125). These intentions, by definition political (i.e., open for discussion and contestation), also have cultural and symbolic powers to compel others to act in desired ways and/or to bestow a capacity for agency to follow or contest. In this article, I have treated infrastructural development projects as political stories that are central to the unfolding of the region-building process around the Bosphorus with identifiable actor-agents, relationships, institutional structures, and dynamics of interest. Artificially developed spaces by means of infrastructures are "shared by many social groups that often have contradictory interests [which] produce an ongoing dynamic of competing options and negotiated decisions in an ever-changing political, economic, and technical context, both in the past and in the present" (van der Vleuten 2010:53). Critics and proponents of infrastructural developmentalism negotiate their competing interests while debating current terms of region building by means of infrastructural projects.

My aim here has been to reflect on the role of material infrastructures in top-down region building and economic integration in Turkey with definite cross-border implications and interventions. Keating, a long-term observer of changes in regional relations in Europe, argued, "Europe has altered the old perspectives on the territorial economy in which peripherality was defined purely in relation to the state capital. New forms of centrality and peripherality have developed in continental space" (Keating 2013:11). My discussion of different infrastructural development projects in energy demonstrates that in today's Europe, regionality is produced through material means of transporting energy commodities from one political ecology to another. Peripheral states champion this effort, but the direction of this move from peripheries (energy resource) to the centers (markets) has not changed. One thing that has changed, though, is that, in the case of Turkey, political integration precedes material infrastructures, as many of my Turkish and non-Turkish European interlocutors have also repeatedly observed. In Turkish elites' peripheral politics, the construction of energy conduits partially catalyzes the state's infrastructural power by 
revitalizing an increasingly stale imaginary of Turkey; in return, and more significantly, an appealing imaginary of Turkey is being mobilized to generate financial and political support for their construction. As Mitchell (2011) has shown for a century ago, the EU core once again prepares for drastic (material and social) infrastructural changes, this time not for the oil age but for a postcarbon society, by capping its dependence on fossil fuels, replacing some of its supply with renewables, and diversifying its dependency on a single provider, and to those ends, by investing in fossil fuels and their infrastructures in its periphery. Yet, infrastructural projects like those I discussed here are historical constructs (Mitchell 2011; van der Vleuten 2010). As such, they are not linear, teleological, inevitable, or unstoppable unfoldings of future history. Rather, they unfold in contradictory and nonlinear ways, in which European, Turkish, and other elite "dreamscapes" of territorial integration, energy hubs, and material power turn into realities that integrate and develop, but in different and far less holistic ways than their architects had imagined.

\section{Acknowledgments}

I thank Cindy Isenhour and Tom Love, editors of this special issue, for inviting me to Austin in the first place to take part in the Society for Economic Anthropology's "Energy and Economy" conference, out of which this article grew. Earlier versions have found audience during the 2013 AAA and 2014 Council for European Studies meetings and during my fellowship at the Institute for Advanced Studies in the Humanities, Binghamton University. My participation in the Azerbaijan Diplomatic Academy's Ninth Baku Summer Energy School considerably improved this final version. I thank Tom Wilson, Doug Rogers, and Denis O'Hearn, as well as the two anonymous reviewers from Economic Anthropology, for their most valuable and thought-provoking engagement with my work.

\section{Notes}

1 After his ruling party's success in 2014 local elections, the Turkish prime minister paid his first visit to the building site of Istanbul's third bridge. The naming of this bridge, in the northeast of the city, after the sixteenth-century Ottoman Sultan Selim I, who ordered the killing of many Anatolian Shias, caused great grief among Turkey's Alevi community.

2 BTC is the world's second longest oil pipeline after the Druzhba pipeline between Russia and Germany and the longest export pipeline transporting oil from the Caspian Sea to Europe via Azerbaijan, Georgia, and Turkey.

3 A busy marketplace in Istanbul known for its shoppers mainly from the postsocialist states in Russia and the Caucasus after the breakup of the Soviets.

\section{References}

Anand, N. 2011 Pressure. Cultural Anthropology 26:542-564.

2012 Municipal Disconnect. Ethnography 13:487-509.

Appadurai, A. 1986 Introduction. In The Social Life of Things. A. Appadurai, ed. Pp. 3-63. Cambridge: Cambridge University Press.

AzerNews 2013 Turkic Speaking States' Coop to Boost Development of Asian Region. http://www.azernews.az/azerbaijan/58238.html, accessed August 16, 2014.

Badenoch, A., and A. Fickers 2010 Introduction. In Materialising Europe. A. Badenoch and A. Fickers, eds. Pp. 1-23. New York: Palgrave Macmillan.

Barry, A. 2013 Material Politics. Malden, MA: John Wiley.

Behrends, A., S. P. Reyna, and G. Schlee 2011 Crude Domination. New York: Berghahn.

Berg, P. O., A. Linde-Laursen, and O. Löfgren 2000 Invoking a Transnational Metropolis. Lund, Sweden: Studentlitteratur.

Bitušíková, A. 2009 Regions and Regionalism in Social Anthropology. Anthropological Journal of European Cultures 18:28-49.

Boissevain, J. 1975 Towards a Social Anthropology of Europe. In Beyond the Community. J. Boissevain and J. Friedl, eds. Pp. 9-17. The Hague: Department of

Educational Science of the Netherlands.

Bowker, G., and S. Starr 1999 Sorting Things Out. Cambridge, MA: MIT Press.

Business Monitor International 2014 Turkey Infrastructure Report Q2. February 6.

Celasun, M., and I. Arslan 2001 State-Owned Enterprises and Privatization in Turkey. In State-Owned Enterprises in the Middle East and North Africa. M.

Celasun, ed. Pp. 224-252. New York: Routledge.

Chelcea, L., and G. Pulay 2015 Networked Infrastructures and the "Local": Flows and Connectivity in a Postsocialist City. City 19:344-355.

Cole, J. W. 1977 Anthropology Comes Part-Way Home. Annual Review of Anthropology 6:349-378.

Collier, S. J. 2011 Post-Soviet Social. Princeton, NJ: Princeton University Press.

Collier, S. J., and N. Kemoklidze 2014 Pipes and Wires. In Globalization in Practice. N. Thrift, A. Tickell, S. Woolgar, and W. H. Rupp, eds. Pp. 69-74. Oxford: Oxford University Press. 


\section{B. Firat}

Dalakoglou, D. 2012 The Road from Capitalism to Capitalism. Mobilities 7:571-586.

Daly, J. 2013 Turkey's Dynamic Railway Expansion Has Larger Regional Implications. Turkey Analyst 6, August 28. http://www.turkeyanalyst.org/

publications/turkey-analyst-articles/item/54-turkeys-dynamic-railway-expansion-has-larger-regional-implications.html, accessed August 17, 2015.

Darian-Smith, E. 1999 Bridging Divides. Berkeley: University of California Press.

de Rijke, K. 2013 Hydraulically Fractured. Anthropology Today 29:13-17.

Dracklé, D., and W. Krauss 2011 Ethnographies of Wind and Power. Anthropology News, May.

Edwards, P. N. 2003 Infrastructure and Modernity. In Modernity and Technology. T. J. Misa, P. Brey, and A. Feenberg, eds. Pp. 185-225. Cambridge, MA: MIT Press.

Edwards, P. N., G. C. Bowker, S. J. Jackson, and R. Williams 2009 Introduction. Journal of the Association for Information Systems 10:364-374.

Elliott, A., and J. Urry 2010 Mobile Lives. London: Routledge.

Energy Market Regulatory Agency 2013 Natural Gas Sector Report. Ankara: EMRA.

European Commission 2010a Energy 2020. COM(2010)639final. Brussels: European Commission.

2010b Energy Infrastructure Priorities for 2020 and Beyond. COM(2010)677final. Brussels: European Commission.

European International Contractors 2012 Turkish International Contracting Services in 2010 and 2011. Newsletter, March 1.

Gluckman, M. 1940 Analysis of a Social Situation in the Zululand. Bantu Studies 14:1-30.

Harvey, P. 2005 The Materiality of State Effects. In State Formation. C. Krohn-Hansen and K. G. Nustad, eds. Pp. 216-247. London: Pluto.

Högselius, P. 2013 Red Gas. New York: Palgrave Macmillan.

Humphrey, C. 2003 Rethinking Infrastructure. In Wounded Cities. J. Schneider and I. Susser, eds. Pp. 91-107. Oxford: Berg.

2005 Ideology in Infrastructure. Journal of Royal Anthropological Institute 11:39-58.

International Crisis Group 2012 Aphrodite's Gift. Europe Report 216. Brussels: ICG.

International Energy Agency 2013 Oil and Gas Security. Paris: IEA.

International Strategic Research Organization 2011 Critical Energy Infrastructure Security Project Final Report. Ankara: USAK.

Johnson, D., and C. Turner 2007 Strategy and Policy for Trans-European Networks. New York: Palgrave Macmillan.

Keating, M. 2013 Rescaling the European State. Oxford: Oxford University Press.

Lakoff, A., and S. J. Collier 2010 Infrastructure and Event. In The Stuff of Politics. B. Braun and S. Whatmore, eds. Pp. 243-266. Minnesota: University of Minnesota Press.

Lampland, M., and S. L. Starr 2009 How to Unravel Standards. In Standards and Their Stories. M. Lampland and S. Leigh Starr, eds. Pp. 207-213. Ithaca, NY: Cornell University Press.

Larkin, B. 2008 Signal and Noise. Durham, NC: Duke University Press.

2013 The Politics and Poetics of Infrastructure. Annual Review of Anthropology 42:327-343.

Latour, B. 1993 We Have Never Been Modern. Cambridge, MA: Harvard University Press.

1996 Aramis, or the Love of Technology. Cambridge, MA: Harvard University Press.

Levinson, M. 2006 The Box. Princeton, NJ: Princeton University Press.

Linde-Laursen, A. 2010 Bordering. Burlington, VT: Ashgate.

Löfgren, 0. 1996 Linking the Local, the National and the Global: Past and Present Trends in European Ethnology. Ethnologia Europaea 26:157-168.

2000 Moving Metaphors. In Invoking a Transnational Metropolis. P. O. Berg, A. Linde-Laursen, and O. Löfgren, eds. Pp. 27-54. Lund, Sweden:

Studentlitteratur.

2004 Concrete Transnationalism? Focaal 43:59-75.

2007 Island Magic and the Making of a Transnational Region. Geographical Review 97:244-259.

2008 Regionauts. European Urban and Regional Studies 15:195-209.

Mann, M. 1984 The Autonomous Power of the State. Archives européenes de sociologie 25:185-213.

Marchand, M. H., M. Boas, and T. M. Shaw 1999 The Political Economy of New Regionalisms. Third World Quarterly 20:897-910.

Marshall, T. 2013 Planning Major Infrastructure. New York: Routledge.

Mason, A., and M. Stoilkova 2012 Corporeality of Consultant Expertise in Arctic Natural Gas Development. Journal of Northern Studies 6:83-96.

McGowan, F. 1999 The Internationalization of Large Technical Systems. In The Governance of Large Technical Systems. O. Coutard, ed. Pp. 130-148. London: Routledge.

McNeish, J.-A., and O. Logan 2012 Flammable Societies. London: Pluto.

Ministry of Transport, Maritime Affairs, and Communications 2011 Ulaşan ve Erişen Türkiye [Turkey reaches and connects]. Ankara: Ministry of Transport,

Maritime Affairs, and Communications.

Mitchell, T. 2002 Rule of Experts. Berkeley: University of California Press.

2011 Carbon Democracy. London: Verso.

Nye, D. E. 2010 When the Lights Went Out. Cambridge, MA: MIT Press.

Peck, F. W. 1995 Regional Development and the Production of Space. Environment and Planning A 28:327-339.

Radikal 2014 Yabancı Elini Cebine Atmadı [The foreigner did not dig into his pocket]. May 13.

http://www.radikal.com.tr/ekonomi/yabanci_elini_cebine_atmadi-1191728, accessed May 13, 2014. 
Reyes, A. S. 2007 Protecting the "Freedom of Transit of Petroleum." Berkeley Journal of International Law 24:842-880.

Rogers, D. 2012 The Materiality of the Corporation. American Ethnologist 39:284-296.

Roth, K. 2007 What's in a Region? In Region, Regional Identity and Regionalism in Southeastern Europe. K. Roth and U. Brunnbauer, eds. Pp. $17-42$. Berlin: LIT.

Schipper, F., and J. Schot 2011 Infrastructural Europeanism, or the Project of Building Europe on Infrastructures. History and Technology 27:245-264.

Schleifer, Y. 2005 Pipeline Politics Give Turkey an Edge. Christian Science Monitor, May 25. http://www.csmonitor.com/2005/0525/p06s01-woeu.html, accessed August 17, 2015.

2013 Is Turkey Becoming a "Constructocracy"? May 9. http://www.eurasianet.org/node/66949, accessed August 17, 2015.

Schneider, P., J. Schneider, and E. E. Hansen 1972 Modernization and Development. Comparative Studies in Society and History 14:328-350.

Schot, J. 2007 Building Europe on Transnational Infrastructures. Journal of Transport History 28:167-171.

Schouten, P. 2013 The Materiality of State Failure. Millennium 41:553-574.

Schueler, J. 2008 Materialising Identity. Amsterdam: Aksant.

Smith, N. 2006[1984] Uneven Development. Athens: University of Georgia Press.

Sovacool, B. K. 2011 The Interpretive Flexibility of Oil and Gas Pipelines. Technological Forecasting and Social Change 78:610-620.

Strauss, S., S. Rupp, and T. Love 2013 Cultures of Energy. Walnut Creek, CA: Left Coast.

Torsello, D. 2013 New Environmentalisms? Farnham, UK: Ashgate.

Tsing, A. 2000 The Global Situation. Cultural Anthropology 15:327-360.

Uzer, U. 2011 Identity and Turkish Foreign Policy. London: I. B. Tauris.

Van der Vleuten, E. 2010 Networked Nation. In Technology and the Making of the Netherlands. J. Schot, A. Rip, and H. Lintsen, eds. Pp. 47-123. Cambridge, MA: MIT Press.

Von Schnitzler, A. 2008 Citizenship Prepaid: Water, Calculability, and Techno-politics in South Africa. Journal of Southern African Studies 34: 899-917.

Watts, M. 2001 Petro-violence. In Violent Environments. N. Peluso and M. Watts, eds. Pp. 189-212. Ithaca, NY: Cornell University Press.

Wedel, J. R., C. Shore, G. Feldman, and S. Lathrop 2005 Toward an Anthropology of Public Policy. Annals of the American Academy of Political and Social Sciences 600:30-51.

Williams, R. 1985 Keywords. New York: Oxford University Press.

Wilson, T. M. 1993 An anthropology of the European Community. In Cultural Change and the New Europe. T. M. Wilson and M. E. Smith, eds. Pp. 1-23. Boulder, CO: Westview.

1998 An Anthropology of the European Union, from Above and Below. In Europe in the Anthropological Imagination. S. Parman, ed. Pp. 148-156. Upper Saddle River, NJ: Simon \& Schuster.

2012 Europe of Regions and Borderlands. In Companion to the Anthropology of Europe. U. Kockel, M. Nic Craith, and J. Frykman, eds. Pp. 163-180. Malden, MA: Wiley-Blackwell.

Winner, L. 1980 Do Artifacts Have Politics? Daedalus 109:121-136.

Winrow, G. M. 2004 Turkey and the East-West Gas Transportation Corridor. Turkish Studies 5:23-42.

Wolf, E. R. 1956 Aspect of Group Relations in a Complex Society. American Anthropologist 58:1065-1078.

Yackley, A. J. 2013 Turkey Realizes Ottoman Dream with Rail Tunnel Linking Europe to Asia. Reuters, October 29.

Ziyadov, T. 2005 Officials Meet to Discuss South Caucasus Rail System. Eurasia Daily Monitor 2(232). 